\title{
Strategy of Police Bureaucracy Reform through Work Ethics Climate, Leadership Commitment, and Organizational Communication Climate against Commitment to Change at the Depok Metro Police
}

\author{
Daru Saputro Wibowo ${ }^{1}$, Mombang Sihite $^{2}$ \\ 1,2 Department of Management, Faculty of Economics and Business, University of Pancasila, Jakarta, Indonesia \\ Corresponding Author: Daru Saputro Wibowo
}

\section{ABSTRACT}

Bureaucracy reform is one of the first steps to support the government's program. It can be used to organize the good, effective, and efficient system of organizing the national police. It can be applied in realizing good governance and clean government towards clean and free of corruption, collusion, and nepotism in the national police. Not only increasing police service excellence but also capacity and accountability of police performance.

Based on these backgrounds, this study aims to determine the description of the strategy for bureaucracy reform of the police, work ethics climate, and leadership commitment. Then, this study also to know the communication climate conditions for the commitment to change at the Depok metro police. This research method used quantitative analysis using the software of Statistical Package for the Social Sciences (SPSS) and Structural Equation Modeling (SEM) Partial Least Square (PLS). In addition, this research also used analysis of SWOT (Strengths, Weaknesses, Opportunities, and Threats) and QSPM (Quantitative Strategic Planning Matrix).

The results show that the bureaucracy reform significantly influences work ethics climate, leadership commitment, organizational communication climate, and commitment to change. The growth or stability of the Depok metro police is in a strong position and on the track with alternative priority strategies using strength and taking advantage of opportunities (Strength -Opportunity). So, it will make the Depok metro police follow the grand strategy of
\end{abstract}

the national policy outlined in the bureaucracy reform. And it is necessary to develop and accelerate the growth of the organization fairly according to its needs.

Keywords: Bureaucracy reform, work ethics, leadership, communication, commitment

\section{INTRODUCTION}

The Indonesian national police (Polri) is an executive agency in government affairs in state order and security throughout the territory of the Indonesian state. The national police have a vital role in the state's life as an instrument of the state as a servant, security, and protector of the community following the law of the Republic of Indonesia number 2 of 2002 concerning the Police of the Republic of Indonesia. It is stated in chapter 2 that the police's function shall be one of the functions of the administration dealt with the defense of public orderliness and safety, law enforcement, protection, safeguard, and services to public.

Bureaucracy reform is one of the first steps in supporting the government's program to organize a good, effective, and efficient police organization system. This step is intended to quickly, accurately, and professionally serve the community in realizing good governance and clean government towards a clean and free of corruption, collusion, and nepotism. Institutionally, the national police are 
Daru Saputro Wibowo et.al. Strategy of police bureaucracy reform through work ethics climate, leadership commitment, and organizational communication climate against commitment to change at the depok metro police.

expected to carry out their duties professionally and proportionally based on professional, moral, and mental capabilities. National police have essential role in maintaining security and order in society and fostering public peace by upholding human rights.

Implementing bureaucracy reform in Indonesia still leaves various challenges ahead that must be gradually and continuously improved. Several strategic problems that still need to be fixed through the implementation of bureaucracy reform include the low commitment of the leadership at the central and regional levels in efforts to prevent and eradicate corruption; performance management is still not fully implemented, human resources management for apparatus (civil servant, national military, and national police) is still not running effectively; public services still do not have the expected quality; the practice of illegal levies in licensing services still occurs; and the practice of public service management has not been carried out correctly.

In the regulation of the ministry of state apparatus utilization and bureaucratic reform no. 11 of 2015 concerning the 20152019 road map, it is stated that there are three indicators of the achievement of bureaucracy reform, namely clean and accountable bureaucracy, effective and efficient bureaucracy, and bureaucracy that has quality public services. Many aspects that become a particular emphasis in bureaucracy reform in Indonesia include the mental apparatus, supervision system, accountability, management, human resources of the apparatus, and the quality of public services. Based on the above background, this study aims to formulate a work ethic strategy, leadership commitment, and communication climate to impact the reform of the Polri bureaucracy at the Depok metro police, Indonesia.

\section{LITERATURE REVIEW Ethical work climate}

Ethical work climate is defined as the prevailing perception of typical organizational practices and procedures with ethical content. It consists of five dimensions which include empathy for others (care), procedures and policies within the organization (rules), laws and codes of ethics (codes of ethics and rules governed by professional bodies and the more extensive social system), ethical beliefs, and individual morals, and dependence on selfinterest (instrumentalism) (Victor \& Cullen, 1988).

Leung (2008) also concludes that a work ethics climate that emphasizes law, code, and independence is more likely to promote performance. In short, according to Luria \& Yagil (2008), perceived fairness in the work environment enhances employee performance-related behavior. Proactive customer service performance causes employees or organizational members to improve processes, anticipate future problems, and maintain persistence in the workplace.

\section{Leadership commitment}

Some literature states that organizational commitment has a positive effect on the achievement of organizational goals. Commitment can be identified within the organization as an important variable in understanding the work behavior of employees or members in the organization. In this regard, Yahaya and Ebrahim (2015) revealed that commitment impacts several attributes related to work, such as intention to stay, absenteeism, job satisfaction, and high commitment. Likewise, recent police research shows that increasing officer commitment effectively prevents job stress, turnover intention, and even destructive behavior. Individual characteristics are police organizational commitment in limited research. Police duty commitment is correlated with leadership, such as transformational leadership. 
Daru Saputro Wibowo et.al. Strategy of police bureaucracy reform through work ethics climate, leadership commitment, and organizational communication climate against commitment to change at the depok metro police.

Transformational leadership is one of the determinants of organizational commitment because transformational leadership can strengthen the positive values of members or officers in the group, namely with five components: vision, inspirational communication, intellectual stimulation, leadership support, and personal recognition (Youngoh Jo and Hoover, 2015). Leadership in organizations takes many forms. According to Jackson, Meyer, and Wang (2012), the spectrum leadership theory focuses on the leadership style expected to have a relationship with member commitment.

\section{Organizational communication climate}

According to Tagiuri (2014), organizational climate is a summary concept outside of the organization's environment, social system, culture, situation, or setting that described the quality of their other variables. Organizational climate summarizes concepts outside the organizational environment, social system, culture, situation, or setting that describe other quality variables. Organizational climate is the quality of the organization's internal environment that lasts a relatively long time, including the experiences of members of the organization, influencing behavior, and can be explained in terms of the value of a set of unique characteristics or attributes of the organization.

According to Tagiuri, organizational communication climate is a relatively enduring quality of the organization's internal environment experienced by its members, influencing their behavior. It can be described in terms of the values of a particular set of environmental characteristics.

\section{Commitment to change}

Herscovitch \& Meyer (2002) define commitment to change as a mindset that encourages individuals to take various actions that are considered necessary in order to implement a change initiation successfully. Herscovitch \& Meyer (2002) proposed three dimensions of change commitment: affective commitment to change, commitment to change continuity, and normative commitment to change.

Commitment to change reflects the individual's commitment to engage in people's behavior to implement a specific work agenda. Commitment is one of the essential factors of the employee or member involvement in supporting change initiatives to provide a critical bond between people and change goals. According to Lundberg (1990), communication in various organizational cases shows that organizational change is facilitated through the communication process.

\section{Bureaucracy reform in Polri}

Bureaucracy reform is an effort to carry out reforms and fundamental changes to the government administration system, especially regarding the implementation of excellent service. The reform of the Polri bureaucracy is no longer a demand of the people who expect that the bureaucracy and especially the Polri apparatus can be of better quality but is a necessity in realizing good governance and clean government. With the passing of the spirit of bureaucracy reform nationally, the national police has implemented the bureaucracy reform program from 2004 to 2014, which is divided into two waves, namely the first wave of bureaucracy reform in 2004-2009 and the second wave of bureaucratic reform in 2011-2014 (Strategic Planning of Polri, 2019).

Bureaucracy reform of the Indonesian national police is a program and activity for revitalizing, structuring, strengthening, revamping, and developing the organization and human resources of the national police in order to obtain adequate and efficient performance (Nasution, 2017). The reform of the Polri bureaucracy is an effort to improve the bureaucratic system that applies within the Polri organization, which is considered no longer following the dynamics of community development as users of Polri services. This assessment 
Daru Saputro Wibowo et.al. Strategy of police bureaucracy reform through work ethics climate, leadership commitment, and organizational communication climate against commitment to change at the depok metro police.

occurs because of the influence of the local, global, and regional environment, which is associated with the current level of community satisfaction who expects transparency, legal certainty, convenience, justice following the main tasks, functions, and roles of the national police (Chrysnanda, 2013).

\section{MATERIALS \& METHODS}

This research was designed using a quantitative and qualitative approach or commonly referred to as a mixed method. The quantitative approach used a survey method, namely a research method that takes samples from a population using a questionnaire as a data collection tool. The aim is to obtain information about the number of respondents who represent a particular population.

In this study, the maximum number of samples was 1600 people from the Depok metro police members. The questionnaire consists of 30 questions from 5 research variables. The sample who filled out the questionnaire was 203 police from various function units and ranks, male and female. Focus Group Discussions (FGDs) were conducted limitedly, either interviewing respondents or open discussions. The analysis was carried out using SPSS and Smart PLS software. Moreover, other analyses using SWOT and QSPM techniques. Based on the theoretical study and framework, hypotheses in this study are:

1. Work ethics climate affects the commitment to change.

2. The work ethics climate affects the achievement of Polri's bureaucracy reform at the Depok metro police.

3. Leadership commitment affects commitment to change.

4. The leadership commitment affects the achievement of Polri's bureaucracy reform at the Depok metro police.

5. Organizational communication climate affects commitment to change.

6. The organizational communication climate affects the achievement of
Polri's bureaucracy reform at the Depok metro police.

7. The work ethic strategy, leadership commitment, and organizational communication climate affect the commitment to change.

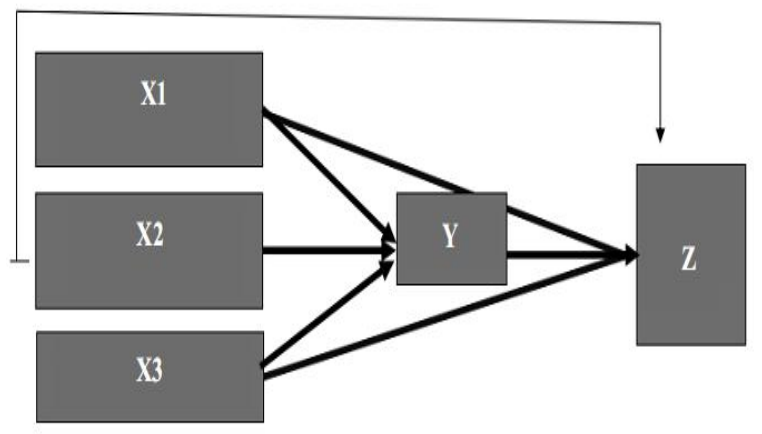

Figure 1. Research variables framework

\section{Descriptions:}

$\mathrm{X} 1$ : Work ethics climate

$\mathrm{X} 2$ : Leadership commitment

$\mathrm{X} 3$ :Organizational communication climate

Y: Commitment to change

Z: Bureaucracy reform

\section{RESULTS \& DISCUSSION Statistical Analysis Results}

The research used Confirmatory Analysis Factor (CFA) for the validity test. The CFA validity test intended to test whether the variables are accurate and incorporated in a one-factor variable. In the validity test, the loading factor must be significant. The significant loading factor may still be of low value, so the standard loading factor estimate must be equal to 0.5 or more. The following are the results of the validity of each variables:

Table 1. Validity variable of work ethics climate

\begin{tabular}{|l|l|l|}
\hline Indicators & Loading Factor Estimate & Validity \\
\hline X11 & 0.68 & Valid \\
\hline X12 & 0.85 & Valid \\
\hline X13 & 0.87 & Valid \\
\hline X14 & 0.78 & Valid \\
\hline X15 & 0.70 & Valid \\
\hline X16 & 0.79 & Valid \\
\hline
\end{tabular}

Table 2. Validity variable of leadership commitment

\begin{tabular}{|l|l|l|}
\hline Indicators & Loading Factor Estimate & Validity \\
\hline X21 & 0.78 & Valid \\
\hline X22 & 0.81 & Valid \\
\hline X23 & 0.81 & Valid \\
\hline
\end{tabular}


Daru Saputro Wibowo et.al. Strategy of police bureaucracy reform through work ethics climate, leadership commitment, and organizational communication climate against commitment to change at the depok metro police.

Table 3. Validity variable of organizational communication climate

\begin{tabular}{|l|l|l|}
\hline Indikator & Loading Factor Estimate & Validity \\
\hline X31 & 0.88 & Valid \\
\hline X32 & 0.77 & Valid \\
\hline X33 & 0.89 & Valid \\
\hline X34 & 0.86 & Valid \\
\hline X35 & 0.8 & Valid \\
\hline
\end{tabular}

Table 4. Validity variable of commitment to change

\begin{tabular}{|l|l|l|}
\hline Indicators & Loading Factor Estimate & Validity \\
\hline Y1 & 0.85 & Valid \\
\hline Y2 & 0.81 & Valid \\
\hline Y3 & 0.67 & Valid \\
\hline
\end{tabular}

Table 5. Validity variable of bureaucracy reform

\begin{tabular}{|l|l|l|}
\hline Indicators & Loading Factor Estimate & Validity \\
\hline Z1 & 0.73 & Valid \\
\hline Z2 & 0.85 & Valid \\
\hline Z3 & 0.87 & Valid \\
\hline Z4 & 0.89 & Valid \\
\hline Z5 & 0.86 & Valid \\
\hline Z6 & 0.72 & Valid \\
\hline Z7 & 0.70 & Valid \\
\hline Z8 & 0.77 & Valid \\
\hline Z9 & 0.84 & Valid \\
\hline Z10 & 0.90 & Valid \\
\hline Z11 & 0.85 & Valid \\
\hline Z12 & 0.69 & Valid \\
\hline Z13 & 0.68 & Valid \\
\hline
\end{tabular}

In the measurement of the outer model, construct reliability testing with composite reliability was also carried out, aiming to prove the instrument's accuracy, consistency, and correctly. To test composite reliability, in Smart PLS can be done by looking at the composite reliability and Cronbach's alpha values of more than 0.5 . Here are the test results, which can be seen in the table 6 :

Table 6. Construct reliability results

\begin{tabular}{|l|l|l|l|}
\hline Variable & $\begin{array}{l}\text { Cronbach's } \\
\text { Alpha }\end{array}$ & $\begin{array}{l}\text { Composite } \\
\text { Reliability }\end{array}$ & $\begin{array}{l}\text { Reabilit } \\
\text { y }\end{array}$ \\
\hline $\begin{array}{l}\text { Organizational } \\
\text { communication } \\
\text { climate }\end{array}$ & 0.874 & 0.906 & Reliable \\
\hline $\begin{array}{l}\text { Leadership } \\
\text { commitment }\end{array}$ & 0.851 & 0.91 & Reliable \\
\hline $\begin{array}{l}\text { Work ethics } \\
\text { climate }\end{array}$ & 0.93 & 0.947 & Reliable \\
\hline $\begin{array}{l}\text { Commitment to } \\
\text { change }\end{array}$ & 0.75 & 0.857 & Reliable \\
\hline $\begin{array}{l}\text { Bureaucracy } \\
\text { reform }\end{array}$ & 0.96 & 0.965 & Reliable \\
\hline
\end{tabular}

The structural model test (inner model) is intended to test the latent construct relationship by showing the value of $\mathrm{R}^{2}$. After that, the structural model was tested using the predictive value - relevance $\left(\mathrm{Q}^{2}\right)$. The following are the results of the analysis with the help of Smart PLS software. Based on Figure 2, the structural model equation can be made as follows:

$\mathrm{Y}=0.042 \mathrm{X} 1+0.254 \mathrm{X} 2+0.640 \mathrm{X} 3+\zeta$

$\mathrm{Z}=0.098 \mathrm{X} 1+0.008 \mathrm{X} 2+0.573 \mathrm{X} 3+$ $0.303 Y+\zeta$

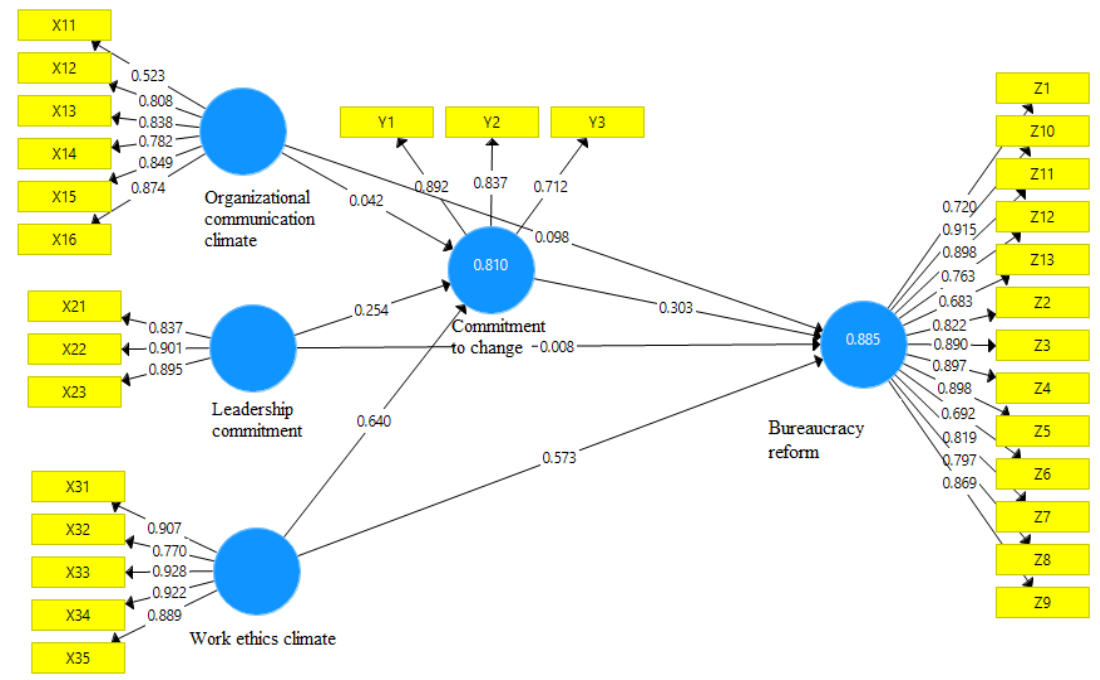

Figure 2. Structural model result

The coefficient of determination is used to determine the contribution of the exogenous latent variable to the endogenous latent variable. According to Hair et al. (2011), an $\mathrm{R}^{2}$ value of more than 0.75 indicates a robust model. Results of the $\mathrm{R}^{2}$ test for the commitment to change variable are 0.810 or $81 \%$. It shows a robust model because the value obtained is more than 0.75 . These results show that organizational communication climate variables, leadership commitment, and work ethic climate influence $81 \%$ on the change commitment variable. In contrast, the remaining 19\% (1- 
Daru Saputro Wibowo et.al. Strategy of police bureaucracy reform through work ethics climate, leadership commitment, and organizational communication climate against commitment to change at the depok metro police.

$\mathrm{R}^{2}$ ) was influenced by other factors not examined.

While the results of the $\mathrm{R}^{2}$ test for the bureaucracy reform variable are 0.885 or $88.5 \%$, it shows a robust model because the value obtained is more than 0.75 . These results show that the variables of organizational communication climate, leadership commitment, work ethics climate, and commitment to change affect $88.5 \%$ on the variable of bureaucracy reform. In contrast, the rest $\left(1-\mathrm{R}^{2}\right)$ of $11.5 \%$ is influenced by other factors not examined.

Predictive-relevance or $\mathrm{Q}^{2}$ aims to measure how well the model's observations and estimates of its parameters. If the value of $\mathrm{Q}^{2}$ is more than zero, it indicates that the model has predictive relevance. Furthermore, if the value of $\mathrm{Q}^{2}$ is less than zero, it indicates that the model lacks predictive relevance. Based on the calculation results, the $\mathrm{Q}^{2}$ value is 0.97815 . It shows that the diversity of research data described by the model is $97.8 \%$. In contrast, the remaining $2.2 \%$ is explained by other factors outside the research model. Therefore, the research model can be declared to have goodness of fit.

In this study, hypothesis testing was carried out with value limits that had been carried out by SEM analysis with Smart PLS software. Smart PLS was bootstrapped to test the hypothesis. The following are the results of hypothesis testing conducted in this study:

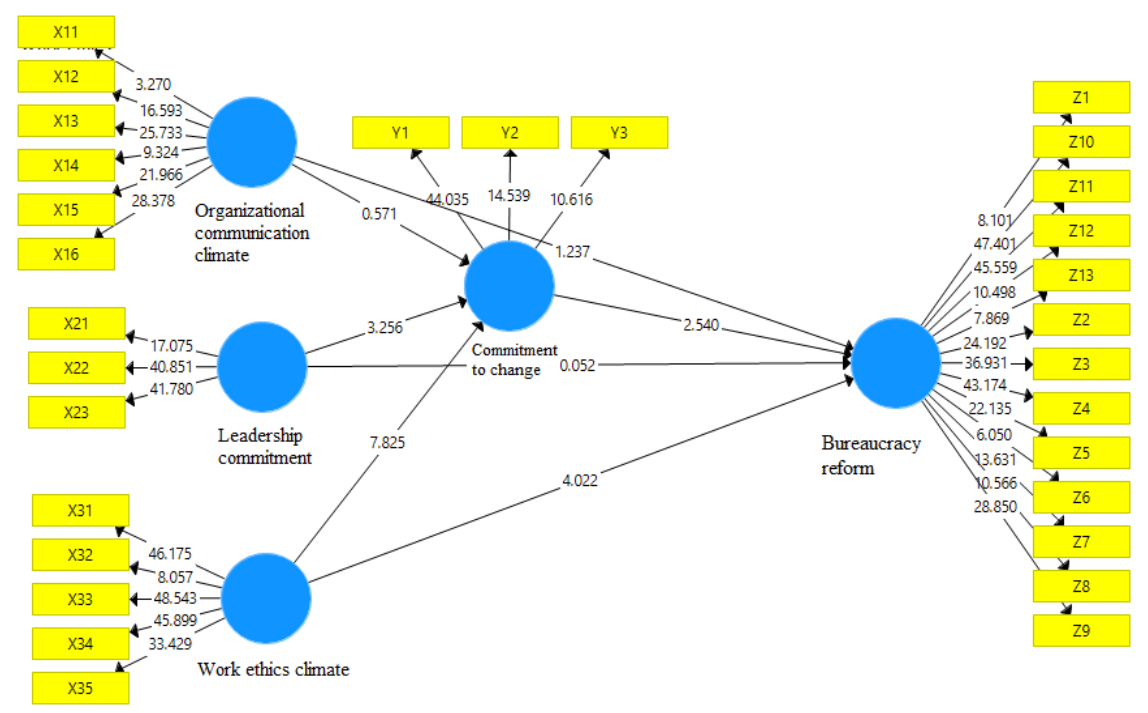

Figure 3. Bootstraping result with Smart PLS

\section{Direct and indirect effect}

Each variable's direct and indirect effects are used to determine the percentage of each variable influenced by the influencing variable. In this study, the variables affected are the variables of commitment to change and bureaucracy reform. The following, in table 7 can be seen the analysis of direct and indirect effects between variables:

Table 7. Direct and indirect effect

\begin{tabular}{|c|c|c|c|c|}
\hline \multicolumn{2}{|l|}{ Direct effect } & \multicolumn{2}{|l|}{ Indirect effect } & Total \\
\hline $\begin{array}{l}\text { Organizational communication climate } \Rightarrow \\
\text { Commitment to change }\end{array}$ & 0.042 & & & 0.042 \\
\hline $\begin{array}{l}\text { Leadership commitment } \Rightarrow \text { Commitment to } \\
\text { change }\end{array}$ & 0.254 & & & 0.254 \\
\hline Work ethics climate $=>$ Commitment to change & 0.64 & & & 0.64 \\
\hline Commitment to change $=>$ Bureaucracy reform & 0.303 & & & 0,303 \\
\hline $\begin{array}{l}\text { Organizational communication climate } \Rightarrow \\
\text { Bureaucracy reform }\end{array}$ & 0.098 & $\begin{array}{l}\text { Organizational communication climate }=>\text { Leadership } \\
\text { commitment }=>\text { Bureaucracy reform }\end{array}$ & 0.013 & 0.111 \\
\hline Leadership commitment $=>$ Bureaucracy reform & 0.008 & $\begin{array}{l}\text { Leadership commitment } \Rightarrow \text { Commitment to } \\
\text { change }=>\text { Bureaucracy reform }(0.254 \times 0.303)\end{array}$ & 0.077 & 0.085 \\
\hline Work ethics climate $=>$ Bureaucracy reform & 0.573 & $\begin{array}{l}\text { Work ethics climate }=>\text { Commitment to change }=> \\
\text { Bureaucracy reform }(0.64 \times 0.303)\end{array}$ & 0.194 & 0.767 \\
\hline
\end{tabular}


Daru Saputro Wibowo et.al. Strategy of police bureaucracy reform through work ethics climate, leadership commitment, and organizational communication climate against commitment to change at the depok metro police.

The direct effect of organizational communication climate on the commitment to change is 0.042 or $4.2 \%$. Meanwhile, the direct influence of organizational communication climate on bureaucracy reform is 0.098 or $9.8 \%$. It shows that the organizational communication climate influences $4.2 \%$ of commitment to change and $9.8 \%$ of police bureaucracy reform. Meanwhile, the indirect effect of organizational communication climate on the commitment to change with bureaucracy reform is 0.111 or $11.1 \%$. In other words, the influence of organizational communication climate through the commitment to change affects bureaucracy reform by $11.1 \%$.

On the other side, the direct effect of leadership commitment to change commitment is 0.254 or $25.4 \%$. In contrast, the direct effect of leadership commitment to bureaucracy reform is 0.008 or $0.8 \%$. It shows that leadership commitment influenced $25.4 \%$ commitment to change and $0.8 \%$ to reform the police bureaucracy. Meanwhile, the indirect effect of leadership commitment to change commitment with bureaucracy reform is 0.085 or $8.5 \%$. In other words, the influence of leadership commitment through commitment to change affects bureaucracy reform by $8.5 \%$.

The direct effect of work ethic climate on the commitment to change is 0.64 or $64 \%$. Meanwhile, the direct influence of work ethic climate on bureaucracy reform is 0.573 or $57.3 \%$. It shows that $64 \%$ of the commitment to change and $57.3 \%$ of the police bureaucracy reform influenced by the work ethics climate. Meanwhile, the indirect effect of work ethic climate on the commitment to change with bureaucracy reform is 0.767 or $76.7 \%$. In other words, the influence of organizational communication climate through a commitment to change affects bureaucracy reform by $76.7 \%$. Based on the direct and indirect effects analysis, the work ethic climate variable has a dominant influence on the variable commitment to change and reform of the Depok metro police bureaucracy reform.

\section{SWOT and QSPM Results}

From table 8 , it is obtained that the value of $X=1.77-1.09=0.68$ and the value of $\mathrm{Y}=1.73-1.02=0.71$, so that the SWOT analysis is in quadrant I. The SWOT analysis results are in quadrant $\mathrm{I}$, which shows that the Depok City Police is in a strong position and is on track. What needs to be done is to develop and accelerate organizational growth. The dominant strategy is on the side of strength and taking advantage of opportunities (SO strategy).

Table 8. Total score SWOT analysis

\begin{tabular}{|l|l|}
\hline \multicolumn{2}{|c|}{ Table 8. Total score SWOT analysis } \\
\hline Strengths & Total score \\
\hline Weaknesses & 1,77 \\
\hline Opportunities & 1,09 \\
\hline Threats & 1,73 \\
\hline
\end{tabular}

SWOT and QSPM analysis results show that the alternative priority strategy is to use strengths and take advantage of opportunities (SO). The first strategy is that the leader motivates and rewards its members. Second, members and leaders are given good facilities and infrastructure fairly according to their needs. Furthermore, the last one fosters a collective conscious attitude between members and leaders with a sense of pride in carrying out each task.

\section{CONCLUSION}

Based on the results of research on the national police bureaucracy reform strategy through work ethics climate, leadership commitment, and organizational communication climate to change commitments and achievements at the Depok metro police, it can be concluded as follows:

1. The variables of work ethics climate, leadership commitment, and organizational communication climate affect commitment to change. While the work ethic climate variable has the most significant influence.

2. The variables of police Bureaucracy reform showed a considerable influence 
Daru Saputro Wibowo et.al. Strategy of police bureaucracy reform through work ethics climate, leadership commitment, and organizational communication climate against commitment to change at the depok metro police.

on the variables of work ethics climate, leadership commitment, organizational communication climate, and commitment to change.

3. The implementation of bureaucracy reform, which was implemented at the Depok metro police, explained that the police bureaucratic reform strategy through a work ethic climate, leadership commitment, and organizational communication climate towards change in implementation went well.

4. The growth or stability of the Depok metro police is in a strong position and on the track with alternative priority strategies using strength and taking advantage of opportunities (Strength Opportunity).

\section{Acknowledgement: None}

\section{Conflict of Interest: None}

\section{Source of Funding: None}

\section{REFERENCES}

1. Alexander Newman, Heather Round, Sukanto Bhattacharya and, Achinto Roy, (2017), Ethical Climates in Organizations: A Review and Research Agenda. Deakin University.

2. Bordia, P., Hunt, E., Paulsen, N., Tourish, D. and DiFonzo, N. (2004). Uncertainty during organizational change: is it all about control. European Journal of Work and Organizational Psychology Vol. 13 No. 3,: 345-365.

3. Choi, M. (2011). Employees attitudes toward organizational change: a literature review. Human Resource Management Vol. 50 No. 4 pp. 479-500.

4. Clayton, J., \& Gregory, W. J. (2000). Reflections on critical systems thinking and the management. Journal of Organizational Change Management.

5. Daru Wibowo Saputro. (2017). Sekolah Tinggi Ilmu Kepolisian (STIK) Jakarta, dan Vindaniar Yuristamanda Putri Program Vokasi, Universitas Indonesia Pengaruh Iklim
Komunikasi Terhadap Komitmen Perubahan Pada Anggota Detasemen D Satuan III Pelopor Korp Brimob Polri Soshum Jurnal Sosial dan Humaniora. Vol.7, No.1, Maret.

6. Kalyal, Hina Jawaid. (2008). Validation of The Herscovitch-Meyer Three-Component Model of Commitment to Change In Pakistan. Sweden: Stockholm University.

7. Klein, S. M. (1996). Management Communication Srategy for Change. Journal of Organizational Change Management 9, 32-46.

8. L, Ming-Chu Y. and Meng-Hsiu. (2015). Unlocking the black box: Exploring the link between perceive organizational support and resistance to change. Asia Pacific Management.

9. Martin, A. J., E. S. Jones, and V. J. Callan. (2005). The role of psychological climate. European Journal of Work and Organizational Psychology 14(3), 263-289.

10. Memon, Mumtaz Ali, Hiram Ting, JunHwa Cheah, Ramayah Thurasamy, Francis Chuah, and Tat Huei Cham. (2020). Sample Size For Survey Research: Review And Recommendations. Journal of Applied Structural Equation Modeling 4(2), i-xx.

11. Meyer, J.P., and N.J. Allen. (1991). Component Conceptualization of Organizational Commitment. Human Resources Management Review. 61-89.

12. Priti Verma, , Dr. (2013). Relationship between Organisational Communication Flow and Communication Climate. International Journal of Pharmaceutical Sciences and Business Management Vol.1 Issue 1: 63-71.

13. Rahmanto, Aris Febri. (2004). Peranan Komunikasi Dalam Suatu Organisasi. Jurnal Komunikologi Vol. 1 No. 2.

14. Roggiest, Sofie, Jesse Segers, dan Arjen van Witteloostuij. (2015). Journal of Organization change Management. Climate, Communication, and participating commitement to change 
Daru Saputro Wibowo et.al. Strategy of police bureaucracy reform through work ethics climate, leadership commitment, and organizational communication climate against commitment to change at the depok metro police.

(Emerald Insight) 28: Vol.28 ISS 6 pp. 11094-1106.

15. Weiner, Bryan J . (2009). A theory of organizational readiness for change. Implementation Science (license BioMed Central Ltd.) 1-9.

16. Youngoh Jo, Hee Sub Shim, and Larry T. Hoover. (2015). Police transformational leadership and organizational commitment: mediating role of organizational. Policing: An
International Journal of Police Strategies \& Management.

How to cite this article: Wibowo DS, Sihite M. Strategy of police bureaucracy reform through work ethics climate, leadership commitment, and organizational communication climate against commitment to change at the depok metro police. International Journal of Research and Review. 2021; 8(8): 722-730. DOI: https:// doi.org/10.52403/ijrr.20210895 